\title{
N-Alkylation of isatins utilizing KF/alumina
}

\author{
Charles M. Clay, Hagar M. Abdallah, Carly Jordan, Kyle Knisley, and Daniel M. Ketcha* \\ Department of Chemistry, Wright State University, Col. Glenn Hwy \\ Dayton $\mathrm{OH}$ 45435, USA \\ E-mail: daniel.ketcha@wright.edu
}

\begin{abstract}
The $\mathrm{N}$-alkylation of isatins by a variety of alkyl halides and one acrylate has been demonstrated utilizing $\mathrm{KF} / \mathrm{Al}_{2} \mathrm{O}_{3}$ in acetonitrile $(\mathrm{ACN})$ under microwave-irradiation $\left(180{ }^{\circ} \mathrm{C}\right)$ or thermally at reflux.
\end{abstract}

Keywords: Isatin, $\mathrm{N}$-alkylation, microwave, $\mathrm{KF} / \mathrm{Al}_{2} \mathrm{O}_{3}$, conjugate addition

\section{Introduction}

Isatins $^{1}$ (and derivatives thereof) represent an important class of "privileged structures'2 capable of serving as ligands for a wide range of biological targets. In order to create the diversity necessary to probe the myriad possible binding partners for this heterocycle, strategies have generally relied upon de novo ring synthesis achieve the desired substitution patterns the benzenoid ring as well as effecting substitution of the isatin nitrogen.

A variety of methods have been demonstrated for the $\mathrm{N}$-alkylation of isatins. Some of the more general methods include the use of sodium hydride in DMF $\left(25-80{ }^{\circ} \mathrm{C}\right)^{3-5}$ or THF $\left(-20{ }^{\circ} \mathrm{C}\right.$ to $\mathrm{rt}),{ }^{6}$ as well as calcium hydride $\left(\mathrm{CaH}_{2}, 40-50{ }^{\circ} \mathrm{C}\right) ;{ }^{7,8}$ conditions which have been found suitable for derivatives with electron withdrawing substituents on the aromatic nucleus. Another general protocol involves the use of $\mathrm{K}_{2} \mathrm{CO}_{3}$ or $\mathrm{Cs}_{2} \mathrm{CO}_{3}$ (1.2 equiv) in DMF (rt to $80{ }^{\circ} \mathrm{C}$ ) in the presence of KI ( 0.2 equiv). ${ }^{9}$ Furthermore, given the susceptibility of 5-nitroisatin to undergo nucleophilic cleavage of the amide bond under basic conditions, a novel modified procedure was developed for $N$-alkylation employing a mild base combination of $\mathrm{CuCO}_{3} / \mathrm{Cs}_{2} \mathrm{CO}_{3}(1: 2)$ in anhydrous DMF $\left(50-70{ }^{\circ} \mathrm{C}\right) .{ }^{10}$

Alternatively, the use of microwave irradiation to expedite this process was first reported by Azizian using $\mathrm{K}_{2} \mathrm{CO}_{3} / \mathrm{DMF}$ or $\mathrm{NaOEt} / \mathrm{EtOH}$ in a conventional microwave oven. ${ }^{11}$ More recently, a comprehensive reinvestigation of this protocol was performed by Perillo et al. who examined a range of bases $\left(\mathrm{Na}_{2} \mathrm{CO}_{3}, \mathrm{~K}_{2} \mathrm{CO}_{3}, \mathrm{Cs}_{2} \mathrm{CO}_{3}, \mathrm{CaH}_{2}\right.$, TEA, LiOH, NMM, NaOEt) in a 
range of solvents (DMF, DMA, HMPT, MeCN, DMSO, NMP) and found the optimal conditions to consist of $\mathrm{K}_{2} \mathrm{CO}_{3}$ or $\mathrm{Cs}_{2} \mathrm{CO}_{3}$ and a few drops of DMF or $N$-methyl-2-pyrrolidinone (NMP). ${ }^{12}$

Lindsley developed a parallel microwave procedure for the preparation of a variety of $\mathrm{N}$ benzyl isatins employing $\mathrm{K}_{2} \mathrm{CO}_{3} / \mathrm{KI}$ in acetonitrile $(\mathrm{ACN})$ under microwave conditions $\left(160{ }^{\circ} \mathrm{C}\right.$, $10 \mathrm{~min}$ ) using a Biotage Initiator-60 instrument, ${ }^{13}$ while Go reported an analogous process in $\operatorname{DMF}\left(150{ }^{\circ} \mathrm{C}, 5-15 \mathrm{~min}\right)$ in a similar microwave reactor. ${ }^{14}$

The N-carboxymethylation of isatin using ethyl bromoacetate has likewise been effected under a variety of conditions, including calcium hydride (DMF, $40{ }^{\circ} \mathrm{C}$ ) 7,8 and under microwave conditions using $\mathrm{K}_{2} \mathrm{CO}_{3}$ or $\mathrm{Cs}_{2} \mathrm{CO}_{3} .{ }^{12}$ More recently, Martin described a protocol for the preparation of (2,3-dioxo-indolin-1-yl)acetamides involving initial $\mathrm{N}$-carboxyalkylation of isatin using ethyl bromoacetate (1.5 equiv) under basic conditions (1.5 equiv of $\mathrm{K}_{2} \mathrm{CO}_{3}$ in DMF, rt, 48 h) in the presence of tetrabutylammonium bromide (TBAB, 0.1 equiv) as the phase transfer catalyst. ${ }^{15}$

Additionally, in regards to devising highly efficient and rapid solution phase methodologies for the parallel synthesis of diverse isatins, Shuttleworth utilized polymer-supported 2-tertbutylimino-2-diethylamino-1,3-dimethylperhydro-1,3,2-diazaphosphorine (BEMP) on polystyrene for the preparation of a library of serine protease inhibitors. ${ }^{16}$ Likewise, Chibale employed the less expensive solid-supported base potassium fluoride on alumina $\left(\mathrm{KF} / \mathrm{Al}_{2} \mathrm{O}_{3}\right)$ as a key step in the N-benzylation of isatins prior to thiosemicarbazone derivatization as inhibitors of cysteine proteases identified in trypanosomes. ${ }^{17}$ However, in the case of the KF/alumina paper it must be observed that no experimental details as to the stoichiometry, temperature or reaction times were provided.

\section{Results and Discussion}

In devising highly efficient and rapid solution phase methodologies for the parallel preparation of diverse isatins, it was envisaged that the use of a solid-supported base under microwave conditions might constitute a useful expedient. ${ }^{18}$ Since it appeared that the $N$-alkylation of isatin had yet to be conducted under microwave conditions using KF/alumina, it was decided to examine the use of this basic catalyst in acetonitrile ( $\mathrm{ACN}$ ) under microwave irradiation in a CEM Discover microwave (300 watts). The initial parameters involved using $\mathrm{KF} / \mathrm{Al}_{2} \mathrm{O}_{3}$ $\left(38 \%,{ }^{19,20} 15\right.$ equiv) for the model reaction of isatin $(0.050 \mathrm{~g})$ and benzyl chloride (1.5 equiv) to

yield 1-benzylindoline-2,3-dione in $\mathrm{ACN}(5 \mathrm{~mL})$ in a microwave vial $(10 \mathrm{~mL})$. Reactions were conducted at temperatures of from $120^{\circ} \mathrm{C}$ to $180{ }^{\circ} \mathrm{C}$ in $20^{\circ} \mathrm{C}$ increments and at time intervals of 10 and $25 \mathrm{~min}$ after which the reactions were monitored by GC/MS to ascertain complete disappearance of starting material. It was found that complete conversion was effected at $180{ }^{\circ} \mathrm{C}$ for $25 \mathrm{~min}$. Using these optimal parameters for time and temperature, it was found that reducing the amount of $\mathrm{KF} / \mathrm{Al}_{2} \mathrm{O}_{3}$ to 5 or 10 equivalents did not result in complete conversion. 
After ascertaining "optimal" conditions for effecting the $N$-benzylation of isatin under microwave irradiation, these conditions were employed to conduct other $N$-alkylation reactions using isatin and solid supported $\mathrm{KF}$ /alumina to produce the desired $\mathrm{N}$-alkylated isatins (Table 1). All microwave reactions were conducted for $25 \mathrm{~min}$ at $180{ }^{\circ} \mathrm{C}$ using $0.3398 \mathrm{mmol}$ of isatin in a $10 \mathrm{~mL}$ microwave vial along with 15 equivalents of $\mathrm{KF} / \mathrm{Al}_{2} \mathrm{O}_{3}(0.773 \mathrm{~g})$ and 1.5 equiv of each alkyl halide in $5 \mathrm{~mL}$ of acetonitrile.
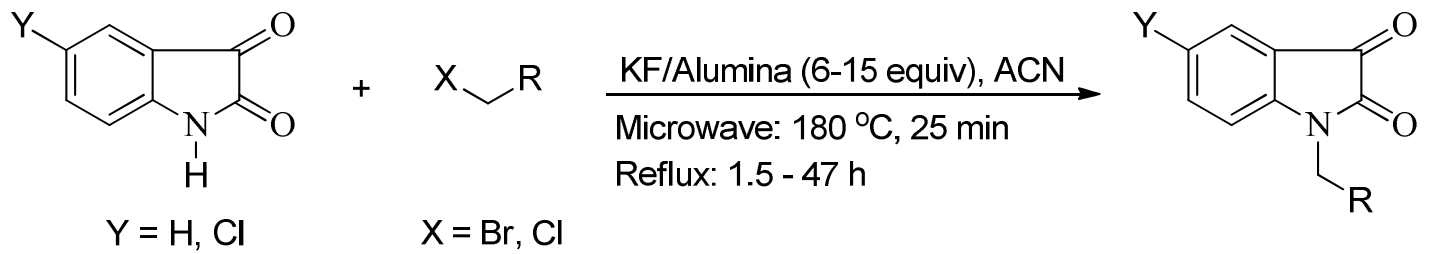

As can be seen from the table, microwave irradiation provides a relatively rapid means of effecting $\mathrm{N}$-alkylations of isatin with a variety of benzylic halides, and ethyl bromoacetate. While the necessity of employing such a large excess of base is unclear (and may be simply attributable to stirring inefficiency), this impediment serves to limit the scale of this process in a practical sense. Moreover, since it was anticipated that the alkylation of isatins bearing electronwithdrawing groups might require even longer reaction times, it was therefore decided to examine the analogous thermal reactions. In the event, it was found that reaction of isatin or 5chloroisatin with alkyl halides in refluxing acetonitrile afforded high yields of products using 6 equiv of KF/alumina in reaction times of $1.5-47 \mathrm{~h}$.

Although an extensive examination of the conjugate addition ${ }^{21}$ of the isatin anion to acrylates was not examined, one reaction is worthy of comment. In the reaction of isatin with tert-butyl acrylate, an intractable red oil was initially obtained. Column chromatography of this crude product led to an orange oil which was then recrystallized from 2-propanol to yield 3-(2,3dioxoindolin-1-yl)propanoic acid. While the point at which the tert-butyl was lost remains obscure, the isolation of the deprotected acid serves as indirect proof of the initial Michael process.

\section{Conclusions}

An examination of the scope and limitations of the $\mathrm{N}$-alkylations of isatins using the solid supported base KF/alumina under microwave-assisted and thermal conditions has been detailed. The reaction under microwave conditions requires the use of 15 equiv of base $\left(38 \% \mathrm{KF} / \mathrm{Al}_{2} \mathrm{O}_{3}\right)$ whereas the reactions conducted at reflux can be effected using six equivalents of base but with extended reaction times. 
Table 1

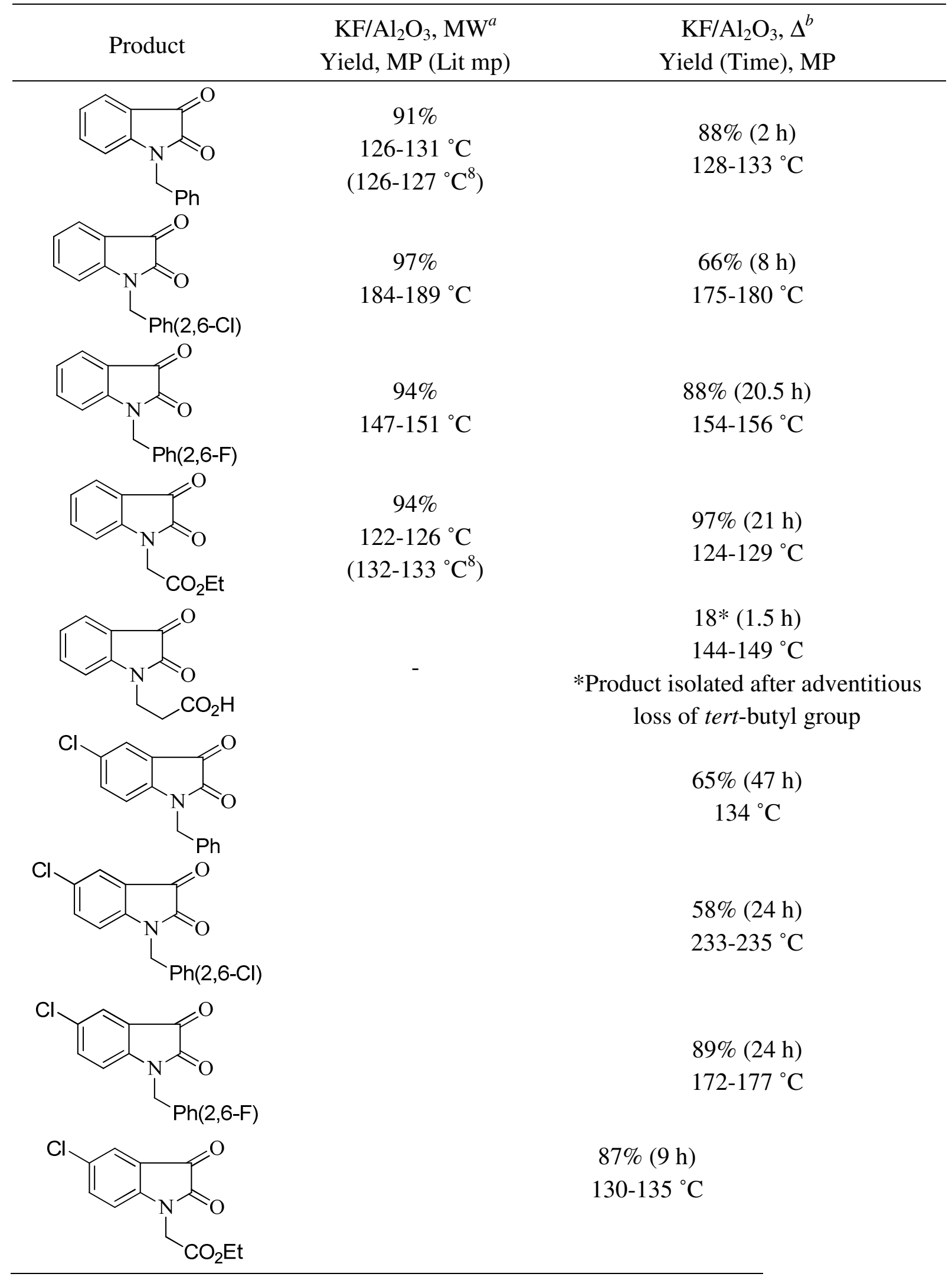




\section{Experimental Section}

General. Melting points were determined via the use of open capillaries with an Electrothermal melting point apparatus and are reported uncorrected. Elemental analyses were performed by Midwest Microlab, Indianapolis, IN. Elemental analysis results are within $+0.4 \%$ of the theoretical values. The ${ }^{1} \mathrm{H}$ and ${ }^{13} \mathrm{C}$ NMR data were obtained on a Bruker Avance $300 \mathrm{MHz}$ NMR in $\mathrm{CDCl}_{3}$ solution unless otherwise indicated. Chemical shifts for proton NMR are reported in $\delta$ (ppm) downfield from tetramethylsilane as an internal standard and ${ }^{13} \mathrm{C}$ NMR shifts are calibrated on the $\mathrm{CDCl}_{3}$ resonance at $77.23 \mathrm{ppm}$ unless otherwise stated. Coupling constants $(J)$ are in Hz. The following abbreviations are used to describe peak patterns where appropriate: $\mathrm{s}$, singlet; $\mathrm{d}$, doublet, dd, double doublet; $\mathrm{t}$, triplet; q, quartet; $\mathrm{dt}$, double triplet; $\mathrm{m}$, multiplet. GC/MS measurements were performed using Hewlett-Packard 6890 Series GC with auto injection and mass fragments are reported a mass per charge, $\mathrm{m} / \mathrm{z}$. The GC was coupled with a mass spectrometer with Hewlett-Packard 5973 mass selective detector/quadrupole system. Flash column (Silica Gel, Premium $\mathrm{R}_{\mathrm{f}}, 200-400$ mesh, Sorbent Technologies) and thin layer chromatography (TLC) were performed on silica gel with indicated solvent systems. All microwave reactions were performed in a monomode MARS Glasschem 300 Watt system by CEM with sample absorption set to "normal".

1-Benzylindoline-2,3-dione. To a solution of isatin ( $7.08 \mathrm{mmol}, 1.042 \mathrm{~g}$ ) in acetonitrile $(70 \mathrm{~mL})$ was added KF/alumina ( 6 equiv, $42.3 \mathrm{mmol}, 6.47 \mathrm{~g}$ ) and the resulting mixture was allowed to stir for 5 min until the initial orange solution turned to a brownish color. After which time, benzyl chloride (1.5 equiv, $10.62 \mathrm{mmol}, 1.22 \mathrm{~mL}$ ) was then added dropwise after which the mixture was refluxed for $2 \mathrm{~h}$. The mixture was allowed to cool to $\mathrm{rt}$ and the suspended KF/alumina was vacuum filtered from the solution and washed with ACN. The filtrate was then evaporated under reduced pressure to afford a solid which was recrystallized from $\mathrm{DCM} /$ hexanes to afford the pure (TLC, GC/MS) product as orange crystals $(1.47 \mathrm{~g}, 88 \%)$ : $\mathrm{mp} 130-132{ }^{\circ} \mathrm{C}$; (lit. ${ }^{8} \mathrm{mp} 126-127{ }^{\circ} \mathrm{C}$ ); $\mathrm{R}_{\mathrm{f}}=0.4(\mathrm{EtOAc} / \mathrm{Hexanes}, 1: 1) ;{ }^{1} \mathrm{H} \mathrm{NMR}\left(300 \mathrm{MHz} \mathrm{CDCl}_{3}\right) \delta 7.62 \mathrm{ppm}(\mathrm{dd}, J=7.2 \mathrm{~Hz}, 0.75 \mathrm{~Hz}$, $1 \mathrm{H}), 7.5(\mathrm{td}, J=7.83 \mathrm{~Hz}, 1.32 \mathrm{~Hz}, 1 \mathrm{H}) 7.41-7.3(\mathrm{~m}, 5 \times \mathrm{Ar}-\mathrm{H}), 7.10(\mathrm{td}, J=7.53 \mathrm{~Hz}, 0.75 \mathrm{~Hz}, 1 \mathrm{H})$, $6.8(\mathrm{~d}, J=7.92 \mathrm{~Hz}, 1 \mathrm{H}), 4.95(\mathrm{~s}, 1 \mathrm{H}) ;{ }^{13} \mathrm{C}$ NMR $\delta: 183.2,158.3,150.7,138.3,134.5,129.1$, 128.2, 127.4, 125.4, 123.8, 117.7, 111.0, $44.1 \mathrm{ppm}$; MS (m/z): $237\left(\mathrm{M}^{+}\right), 146(100 \%)$.

1-(2,6-Dichlorobenzyl)indoline-2,3-dione. To a solution of isatin $(3.39 \mathrm{mmol}, 0.5 \mathrm{~g})$ in acetonitrile $(115 \mathrm{~mL})$ was added $\mathrm{KF} /$ alumina $(20.4 \mathrm{mmol}, 3.12 \mathrm{~g})$ and the resulting mixture was allowed to stir for $5 \mathrm{~min}$ until the initial orange solution turned to a brownish color. After which time, 2,6-dichlorobenzyl bromide ( 1.5 equiv, $5.1 \mathrm{mmol}, 1.22 \mathrm{~g}$ ) was added and the mixture was then refluxed under acetonitrile for $8 \mathrm{~h}$. The mixture was then allowed to cool to $\mathrm{rt}$ and the suspended KF/alumina was vacuum filtered from the solution and washed with ACN. The filtrate was then evaporated under reduced pressure to afford a solid which was recrystallized from chloroform/hexanes to afford the pure (TLC, GC/MS) product as orange crystals $(3.04 \mathrm{~g}, 66 \%)$ : mp 175-180 ${ }^{\circ} \mathrm{C} ; \mathrm{R}_{\mathrm{f}}=0.73($ EtOAc/hexanes, $1: 1) ;{ }^{1} \mathrm{H}$ NMR $\left(300 \mathrm{MHz} \mathrm{CDCl}_{3}\right) \delta 7.61 \mathrm{ppm}(\mathrm{dd}, J$ 
$=7.47 \mathrm{~Hz}, 0.75 \mathrm{~Hz}, 1 \mathrm{H}), 7.46(\mathrm{td}, J=7.83 \mathrm{~Hz}, 1.35 \mathrm{~Hz}, 1 \mathrm{H}), 7.39(\mathrm{~d}, J=8.31 \mathrm{~Hz}, 1 \mathrm{H}), 7.28(\mathrm{~d}, J=$ $7.23 \mathrm{~Hz}, 1 \mathrm{H}), 7.26(\mathrm{t}, J=6.51 \mathrm{~Hz}, 1 \mathrm{H}), 7.08(\mathrm{t}, J=7.56 \mathrm{~Hz}, 1 \mathrm{H}), 6.75(\mathrm{~d}, J=7.89 \mathrm{~Hz}, 1 \mathrm{H}), 5.26(\mathrm{~s}$, $2 \mathrm{H}) ;{ }^{13} \mathrm{C}$ NMR $\delta: 182.9,157.7,150.4,138.4,136.4,130.3,129.2,129.1,125.3,123.6,117.9$, 111.1, 40.3 ppm; $\mathrm{MS}(\mathrm{m} / z): 305\left(\mathrm{M}^{+}\right), 270$ (100\%); Anal. Calcd for $\mathrm{C}_{15} \mathrm{H}_{9} \mathrm{Cl}_{3} \mathrm{NO}_{2}$ : C, 58.85; $\mathrm{H}$, 2.96; N, 4.58 Found: C, 58.77; H, 3.04; N, 4.57 .

1-(2,6-Difluorobenzyl)indoline-2,3-dione. ${ }^{13}$ To a solution of isatin $(6.84 \mathrm{mmol}, 1.01 \mathrm{~g})$ in acetonitrile $(70 \mathrm{~mL}$ ), was added $\mathrm{KF} /$ alumina (6 equiv, $40.7 \mathrm{mmol}, 6.40 \mathrm{~g}$ ) and the resulting mixture was allowed to stir for 5 min until the initial orange solution turned to a brownish color. After which time, 2,6-difluorobenzyl bromide (1.5 equiv., $10.2 \mathrm{mmol}, 2.11 \mathrm{~g}$ ) was added and the mixture was then refluxed under acetonitrile for $20.5 \mathrm{~h}$. The mixture was then allowed to cool to rt and the suspended KF/alumina was vacuum filtered from the solution and washed with ACN. The filtrate was then evaporated under reduced pressure to afford a solid which was recrystallized from DCM/hexanes to afford the pure (TLC, GC/MS) product as brown crystals (1.64 g, 88\%): mp 154-156 ${ }^{\circ} \mathrm{C} ; \mathrm{R}_{\mathrm{f}}=0.46$ (EtOAc/hexanes, $\left.1: 1\right) ;{ }^{1} \mathrm{H} \mathrm{NMR}\left(300 \mathrm{MHz} \mathrm{CDCl}_{3}\right) \delta$ $7.60 \mathrm{ppm}(\mathrm{dd}, J=7.47 \mathrm{~Hz}, 0.75 \mathrm{~Hz}, 1 \mathrm{H}), 7.53(\mathrm{t}, J=7.83 \mathrm{~Hz}, 1 \mathrm{H}), 7.32(\mathrm{~m}, 1 \mathrm{H}), 7.10(\mathrm{t}, J=$ $7.52 \mathrm{~Hz}, 1 \mathrm{H}), 6.94(\mathrm{t}, J=8.22 \mathrm{~Hz}, 1 \mathrm{H}), 5.03(\mathrm{~s}, 1 \mathrm{H}) ;{ }^{13} \mathrm{C} \mathrm{NMR} \delta: 182.9,163.2,159.9,157.5$, $150.4,138.4,130.5,125.3,123.8,117.7,111.8,110.3,110.3,32.2 \mathrm{ppm} ; \mathrm{MS}(\mathrm{m} / \mathrm{z}): 273\left(\mathrm{M}^{+}\right.$, $100 \%)$.

Ethyl 2-(2,3-dioxoindolin-1-yl)acetate. To a solution of isatin (3.4 mmol, $0.503 \mathrm{~g})$ in acetonitrile $(35 \mathrm{~mL})$, was added KF/alumina $(20.39 \mathrm{mmol}, 3.201 \mathrm{~g}$ ) and the resulting mixture was allowed to stir for $5 \mathrm{~min}$ until the initial orange solution turned to a brownish color. After which time, ethyl bromoacetate ( 1.5 equiv., $5.09 \mathrm{mmol}, 5.28 \mathrm{~g}, 0.567 \mathrm{~mL}$ ) was pipetted into the round bottom flask after which the time the mixture was then refluxed for $21 \mathrm{~h}$. The mixture was then allowed to cool to $\mathrm{rt}$ and the suspended KF/alumina was vacuum filtered from the solution and washed with ACN. The filtrate was evaporated to afford the pure (TLC, GC/MS) yellow solid product $(0.77 \mathrm{~g}, 97 \%)$ : $\mathrm{mp} 124-129{ }^{\circ} \mathrm{C}$; (lit. $\left.{ }^{8} \mathrm{mp} 132-133{ }^{\circ} \mathrm{C}\right) ; \mathrm{R}_{\mathrm{f}}=0.51($ EtOAc/hexanes, $1: 1) ;{ }^{1} \mathrm{H}$ NMR $\left(300 \mathrm{MHz} \mathrm{CDCl}_{3}\right) \delta 7.64 \mathrm{ppm}(\mathrm{dd}, J=7.56 \mathrm{~Hz}, 0.75 \mathrm{~Hz}, 1 \mathrm{H}), 7.6(\mathrm{td}, J=7.83 \mathrm{~Hz}$, $1.35 \mathrm{~Hz}, 1 \mathrm{H}), 7.16(\mathrm{td}, J=7.54 \mathrm{~Hz}, 0.72 \mathrm{~Hz}, 1 \mathrm{H}), 6.81(\mathrm{~d}, J=7.98 \mathrm{~Hz}, 1 \mathrm{H}), 4.49(\mathrm{~s}, 2 \mathrm{H}), 4.25(\mathrm{q}, J$ $=7.15 \mathrm{~Hz}, 2 \mathrm{H}), 1.29(\mathrm{t}, J=7.08 \mathrm{~Hz}, 3 \mathrm{H}) ;{ }^{13} \mathrm{C}$ NMR $\left(300 \mathrm{MHz}\right.$ DMSO- $\left.d_{6}\right) \delta: 182.6,167.3,158.2$, 150.3, 138.5, 124.5, 123.7, 117.2, 111.2, 61.3, 41.2, 14.0 ppm; MS (m/z): $233\left(\mathrm{M}^{+}\right), 132(100 \%)$.

3-(2,3-Dioxoindolin-1-yl)propanoic acid. To a solution of isatin $(2.5 \mathrm{mmol}, 0.3678 \mathrm{~g})$ in acetonitrile $(30 \mathrm{~mL})$ was added $\mathrm{KF} /$ alumina $(19.0 \mathrm{mmol}, 2.91 \mathrm{~g})$ and the resulting mixture was allowed to stir for 10 min until the initial orange solution turned to a dark brownish color. After which time, tert-butyl acrylate (3.0 equiv, $7.50 \mathrm{mmol}, 0.961 \mathrm{~g}, 1.089 \mathrm{~mL}$ ) was then added to the stirred solution after which time the mixture was refluxed for $1.5 \mathrm{~h}$. The mixture was then allowed to cool to $\mathrm{rt}$ and the suspended KF/alumina was vacuum filtered from the solution, to give a impure red oil. A silica gel column (hexanes/EtOAc, 70:30) was used to purify separate the product from impurities to give a red solid. The solid was then recrystallized from 2-propanol to afford the carboxylic acid product as red crystals $(0.1256 \mathrm{~g}, 18 \%): \mathrm{mp} 144-149{ }^{\circ} \mathrm{C} ; \mathrm{R}_{\mathrm{f}}=0.53$ (EtOAc/hexanes, 1:1) ${ }^{1} \mathrm{H}$ NMR (300 MHz DMSO- $\left.d_{6}\right) \delta 12.41 \mathrm{ppm}(\mathrm{s}, 1 \mathrm{H}), 7.66(\mathrm{~d}, J=7.76 \mathrm{~Hz}$, 
$1 \mathrm{H}), 7.54(\mathrm{~d}, J=7.32 \mathrm{~Hz}, 1 \mathrm{H}), 7.24(\mathrm{~d}, J=7.89 \mathrm{~Hz}, 1 \mathrm{H}), 7.12(\mathrm{t}, J=7.47 \mathrm{~Hz}, 1 \mathrm{H}), 3.89(\mathrm{t}, J=$ $7.28 \mathrm{~Hz}, 2 \mathrm{H}), 2.62(\mathrm{t}, J=7.19 \mathrm{~Hz}, 2 \mathrm{H}) ;{ }^{13} \mathrm{C} \mathrm{NMR} \delta: 183.4,172.2,158.0,150.4,138.1,124.4$, 123.1, 117.5, 110.9, 35.6, 31.4 ppm; Anal. Calcd for $\mathrm{C}_{11} \mathrm{H}_{9} \mathrm{NO}_{4}$ : C, 60.27; H, 4.14; N, 6.39. Found: C, 60.34; H, 4.36; N, 6.30.

1-Benzyl-5-chloroindoline-2,3-dione. ${ }^{17}$ To a solution of 5-chloroisatin $(5.51 \mathrm{mmol}, 1.00 \mathrm{~g})$ in acetonitrile $(70 \mathrm{~mL})$, was added $\mathrm{KF} /$ alumina $(33.04 \mathrm{mmol}, 5.19 \mathrm{~g})$ and the resulting mixture was allowed to stir for $10 \mathrm{~min}$ until the initial orange solution turned to a dark brownish color. After which time, benzyl chloride (1.5 equiv, $8.26 \mathrm{mmol}, 0.952 \mathrm{~mL}$ ) was then added dropwise and the mixture was refluxed for $47 \mathrm{~h}$. The mixture was then allowed to cool to $\mathrm{rt}$ and the suspended KF/alumina was vacuum filtered from the solution and washed with ACN. The filtrate was evaporated under reduced pressure to afford a solid which was recrystallized from ethanol to afford the pure (TLC, GC/MS) product as orange crystals $(1.20 \mathrm{~g}, 65 \%): \mathrm{mp} 134{ }^{\circ} \mathrm{C} ; \mathrm{R}_{\mathrm{f}}=0.65$ (EtOAc/hexanes, 1:1) ${ }^{1} \mathrm{H}$ NMR $\left(300 \mathrm{MHz} \mathrm{CDCl}_{3}\right) \delta 7.57 \mathrm{ppm}(\mathrm{d}, J=2.22 \mathrm{~Hz}, 1 \mathrm{H}), 7.45(\mathrm{dd}, J=$ $8.43 \mathrm{~Hz}, 2.2 \mathrm{~Hz}, 1 \mathrm{H}), 7.37-7.31(\mathrm{~m}, 5 \times \mathrm{Ar}-\mathrm{H}), 6.75(\mathrm{~d}, J=8.34 \mathrm{~Hz}, 1 \mathrm{H}), 4.94(\mathrm{~s}, 2 \mathrm{H}) ;{ }^{13} \mathrm{C} \mathrm{NMR}$ $\delta: 182.2,157.7,149.0,137.7,134.2,129.7,129.2,128.4,127.4,125.3,118.6,112.3,44.1$ ppm; MS (m/z): $271\left(\mathrm{M}^{+}\right), 180(100 \%)$.

1-(2,6-Dichlorobenzyl)-5-chloroindoline-2,3-dione. To a solution of 5-chloroisatin (2.76 mmol, $0.5036 \mathrm{~g})$ in acetonitrile $(35 \mathrm{~mL})$ was added $\mathrm{KF} /$ alumina $(16.56 \mathrm{mmol}, 2.50 \mathrm{~g})$ and the resulting mixture was allowed to stir for 10 min until the initial orange solution turned to a dark brownish color. After which time, 2,6-dichlorobenzyl bromide (1.5 equiv., 4.13 mmol, $0.9901 \mathrm{~g}$ ) was added and the mixture was refluxed for $24 \mathrm{~h}$. The mixture was then allowed to cool to rt and the suspended KF/alumina was vacuum filtered from the solution and washed with ACN to afford the pure (TLC, GC/MS) orange solid (0.5478 g, 58\%): mp 233-235 ${ }^{\circ} \mathrm{C} ; \mathrm{R}_{\mathrm{f}}=0.67$ (EtOAc/hexanes, 1:1); ${ }^{1} \mathrm{H}$ NMR (300 MHz DMSO- $\left.d_{6}\right) \delta 7.71 \mathrm{ppm}(\mathrm{dd}, J=8.49 \mathrm{~Hz}, 2.30 \mathrm{~Hz}, 1 \mathrm{H})$, $7.66(\mathrm{~d}, J=2.31 \mathrm{~Hz}, 1 \mathrm{H}), 7.54(\mathrm{~d}, J=8.01 \mathrm{~Hz}, 1 \mathrm{H}), 7.42(\mathrm{t}, 7.92 \mathrm{~Hz}, 1 \mathrm{H}), 7.00(\mathrm{~d}, J=8.37 \mathrm{~Hz}$, 1H), $5.13(\mathrm{~s}, 2 \mathrm{H}) ;{ }^{13} \mathrm{C}$ NMR $\delta: 181.7,157.5,149.2,137.3,135.4,130.8,129.5,129.1,127.7$, 124.2, 119.0, 112.6, 40.4; MS (m/z): $339\left(\mathrm{M}^{+}\right), 180$ (100\%); Anal. Calcd for $\mathrm{C}_{15} \mathrm{H}_{8} \mathrm{Cl}_{3} \mathrm{NO}_{2}$ : C, 52.90; H, 2.37; N, 4.11 Found: C, 52.76; H, 2.46; N, 4.07.

1-(2,6-Difluorobenzyl)-5-chloroindoline-2,3-dione. ${ }^{13}$ To a solution of 5-chloroisatin (2.76 mmol, $0.502 \mathrm{~g}$ ) in acetonitrile $(35 \mathrm{~mL})$, was added KF/alumina (17 mmol, $2.6 \mathrm{~g})$ and the resulting mixture was allowed to stir for $10 \mathrm{~min}$ until the initial orange solution turned to a dark brownish color, inside a $250 \mathrm{~mL}$ round bottom. After which time, 2,6-difluorobenzyl bromide ( 1.5 equiv., $4.15 \mathrm{mmol}, 0.85 \mathrm{~g}$ ) was added and the mixture was refluxed for $24 \mathrm{~h}$. The mixture was then allowed to cool to $\mathrm{rt}$ and the suspended KF/alumina was vacuum filtered from the solution and washed with ACN. The filtrate was then evaporated under reduced pressure to afford a solid which was recrystallized from DCM/hexanes to afford the pure (TLC, GC/MS) product as reddish-violet crystals $(0.76 \mathrm{~g}, 89 \%): \mathrm{mp} 172-177{ }^{\circ} \mathrm{C} ; \mathrm{R}_{\mathrm{f}}=0.46($ EtOAc/hexanes, $1: 1) ;{ }^{1} \mathrm{H}$ NMR $\left(300 \mathrm{MHz} \mathrm{CDCl}_{3}\right) \delta 7.57 \mathrm{ppm}(\mathrm{d}, J=2.07 \mathrm{~Hz}, 1 \mathrm{H}), 7.50(\mathrm{dd}, J=8.25 \mathrm{~Hz}, 2.27 \mathrm{~Hz}$, $1 \mathrm{H}), 7.39-7.28(\mathrm{~m}, 1 \mathrm{H}), 6.96(\mathrm{t}, J=8.15 \mathrm{~Hz}, 1 \mathrm{H}), 6.75(\mathrm{~d}, 8.55 \mathrm{~Hz}, 1 \mathrm{H}), 4.94(\mathrm{~s}, 2 \mathrm{H}) ;{ }^{13} \mathrm{C} \mathrm{NMR} \delta$ : 
181.8, 163.2, 159.7, 156.9, 148.5, 137.8, 130.8, 129.7, 125.2, 118.6, 111.9, 111.6, 109.9, 32.4; MS (m/z): $307\left(\mathrm{M}^{+}, 100 \%\right)$.

Ethyl 2-(5-chloro-2,3-dioxoindolin-1-yl)acetate. ${ }^{15}$ To a solution of 5-chloroisatin (2.76 mmol, $0.501 \mathrm{~g}$ ) in acetonitrile $(35 \mathrm{~mL})$, was added $\mathrm{KF} /$ alumina $(16.5 \mathrm{mmol}, 2.61 \mathrm{~g})$ and the resulting mixture was allowed to stir for 10 min until the initial orange solution turned to a dark brownish color. After which time, ethyl bromoacetate (1.5 equiv., $4.13 \mathrm{mmol}, 0.734 \mathrm{~mL}$ ) was added and the mixture was refluxed for $9 \mathrm{~h}$. The mixture was then allowed to cool to $\mathrm{rt}$ and the suspended KF/alumina was vacuum filtered from the solution and washed with ACN. The filtrate evaporated to afford the pure (TLC, GC/MS) yellow solid $(0.64 \mathrm{~g}, 87 \%)$ : $\mathrm{mp} 130-135{ }^{\circ} \mathrm{C} ; \mathrm{R}_{\mathrm{f}}=$ 0.68 (EtOAc/hexanes, $1: 1) ;{ }^{1} \mathrm{H}$ NMR $\left(300 \mathrm{MHz}\right.$ DMSO- $\left.d_{6}\right) \delta 7.75 \mathrm{ppm}(\mathrm{dd}, J=8.55 \mathrm{~Hz}, 2.22 \mathrm{~Hz}$, $1 \mathrm{H}), 7.67(\mathrm{~d}, J=2.01 \mathrm{~Hz}, 1 \mathrm{H}), 7.25(\mathrm{~d}, J=8.46 \mathrm{~Hz}, 1 \mathrm{H}), 4.63(\mathrm{~s}, 2 \mathrm{H}), 4.17(\mathrm{q}, 7.08 \mathrm{~Hz}, 2 \mathrm{H}), 1.22$ $(\mathrm{t}, J=7.13 \mathrm{~Hz}, 3 \mathrm{H}) ;{ }^{13} \mathrm{C}$ NMR $\delta: 181.5,167.3,157.8,148.9,137.4,127.9,124.1,118.6,112.9$, 61.4, 41.3, 14.0; MS (m/z): $267\left(\mathrm{M}^{+}\right), 166(100 \%)$.

\section{Acknowledgements}

National Science Foundation - Course, Curriculum, and Laboratory Improvement (CCLI) Instructional Materials Development (DUE-0127240), Procter \& Gamble Fund, Curriculum Development Grant for Rapid Transfer of Knowledge and Technology

\section{References}

1. For a review on the chemistry of isatins, see: Silva, J. F.; Garden, S. J.; Pinto, A. C. J. Braz. Chem. Soc. 2001, 12, 273-324.

2. Evans, B. E.; Rittle, K. E.; Bock, M. G.; DiPardo, R. M.; Freidinger, R. M.; Whitter, W. L.; Lundell, G. F.; Veber, D. F.; Anderson, P. S.; Chang, R. S. L.; Lotti, V. J.; Cerino, D. J.; Chen, T. B.; Kling, P. J.; Kunkel, K. A.; Springer, J. P.; Hirshfieldt, J. J. Med. Chem. 1988, 31, 2235-2246.

3. Von Tacconi, G.; Righetti, P. P.; Desimiomi, G. J. Prakt. Chem. 1973, 315, 339-344.

4. Lee, D.; Long, S. A.; Adams, J. L.; Chan, G.; Vaidya, K. S.; Francis, T. A.; Kikly, K.; Winkler, J. D.; Sung, C.-M.; Debouck, C.; Richardson, S.; Levy, M. A.; DeWolf, W. E., Jr.; Keller, P. M.; Tomaszek, T.; Head, M. S.; Ryan, M. D.; Haltiwanger, R. C.; Liang, P.-H.; Abdel-Meguid, S. S.; Badger, A. M.; Lark, M. W.; Nadeau, D. P.; Suva, L. J.; Gowen, M.; Nuttall, M. E. J. Biol. Chem. 2000, 275, 16007-16014.

5. Chu, W.; Zhang, J.; Zeng, C.; Rothfuss, J.; Tu, Z.; Reichert, D. E.; Welch, M. J.; Mach, R. H. J. Med. Chem. 2005, 48, 7637-7647.

6. Singh, R. P.; Majumder, U.; Shreeve, J. J. Org. Chem. 2001, 66, 6263-6267. 
7. Garden, S. J.; Torres, J. C.; Da Silva,, L. E.; Pinto, S. C. Synth. Commun. 1998, 28, 16791689.

8. Lotter, A. N. C.; Pathak, P. R.; Sello, T. S.; Fernandes, M. A.; van Otterlo, W. A. L.; de Konig, C. B. Tetrahedron 2007, 63, 2263-2274.

9. Vine, K. L.; Locke, J. M.; Ranson, M.; Pyne, S. G.; Bremner, J. B. J. Med. Chem. 2007, 50, 5109-5117.

10. Torisawa, Y.; Nishi, Minamikawa, J.-I. Bioorg. Med. Chem. Lett. 2001, 11, 829-832.

11. Azizian, J.; Fallah-Bagher-Shaidaei, H.; Kefayati, H. Synth. Commun. 2003, 33, 789-793.

12. Schmidt, M. S.; Reverdito, A. M.; Kremenchuzky, L.; Perillo, I. A.; Blanco, M. M. Molecules, 2008, 13, 831-840.

13. Bridge, T. M.; Marlo, J. E.; Niswender, C. M.; Jones, C. K.; Jadhav, S. B.; Gentry, P. R.; Plumsley, H. C.; Weaver, C. D.; Conn, P. J.; Lindsley, C. W. J. Med. Chem. 2009, 52, 34453448.

14. Wee, X. K.; Yeo, W. K.; Zhang, B.; Tan. V. B. C.; Lim, K. M.; Tay, T. E.; Go, M.-L. Bioorg. Med. Chem. 2009, 17, 7562-7571.

15. Bouhfid, R.; Joly, N.; Ohmani, F.; Essassi, E.M.; Lequart, V.; Banoub, J.; Kheddid, K.; Charof, R.; Massoui, M.; Martin, P. Lett. Org. Chem. 2008, 5, 3-7.

16. Shuttleworth, S.J.; Nasturica, D.; Gervais, C.; Siddiqui, M.A.; Rando, R.F.; Lee, N. Bioorg. Med. Chem. Lett. 2000, 10, 2501-2504.

17. Chiyanzu, I.; Hansell, E.; Gut, J.; Rosenthal, P.J.; McKerrow, J.H.; Chibale, K. Bioorg. Med. Chem. Lett. 2003, 13, 3527-3530.

18. For reviews on microwave chemistry, see: a) Dallinger, D.; Kappe, C.O. Chem. Rev. 2007, 107, 256; b) Kappe, C. O.; Dallinger, D.; Murphree, S. S. Practical Microwave Synthesis for Organic Chemists; VCH, Weinheim, 2008.

19. For a review on $\mathrm{KF} / \mathrm{Al}_{2} \mathrm{O}_{3}$ mediated organic synthesis, see: Blass, B. E. Tetrahedron 2002, 58, 9301-9320.

20. For the preparation of KF/alumina, see: Yadav, V. K.; Kapoor, K. K. Tetrahedron 1996, 52, 3659-3668.

21. For an example of the conjugate addition of isatin to acrylonitrile, see: Di Carlo, F. J.; Lindwall, H. G. J. Am. Chem. Soc. 1945, 67, 199-201. 